\title{
A Marine Natural Products as Modulators of Multidrug Resistance
}

\author{
Tatjana P. Stanojkovic ${ }^{1, *}$ and Sanja Milovic ${ }^{2}$ \\ ${ }^{1}$ Institute of Oncology and Radiology of Serbia, Pasterova 14, 11000 Belgrade, Serbia \\ ${ }^{2}$ Faculty of Pharmacy, University of Belgrade, VojvodeStepe 450, 11221 Belgrade, Serbia
}

\begin{abstract}
Multidrug resistance (MDR) which enable the tumor cells to possess intrinsic or acquired cross resistance to multiple chemotherapeutic agents simultaneously is considered to be a major challenge in cancer chemotherapy during the 21st century. numerous efflux pumps and transport proteins have been found to play important roles in MDR either the phenomenon of lowering the total intracellular retention of chemotherapeutic drugs or the redistribution of intracellular accumulation of drugs away from target organelles are two of the basic mechanisms involved in this process of MDR by transmembrane proteins which are expressed in varying concentrations in different neoplasms. Multiple compounds that have the potential to inhibit these pumps or proteins can be a future prospective for adjuvant treatment of neoplastic conditions. In this regard, compounds derived from natural products bear the advantages of low-cost and relative nontoxicity thus providing a great pool of lead structures for chemical derivatizations. This review gives an overview on chemical substances isolated from natural products of marine origin which possess the MDR modulating properties
\end{abstract}

Keywords: Multidrug resistance, Chemotherapy, ABC transporters, P-glycoprotein, MDR modulators, Cytoprotective activity, Quantitative structure-activity relationship (QASR).

\section{INTRODUCTION}

Chemotherapy is the most effective treatment for patients with cancer. However, the success of chemotherapy is seriously limited by the phenomenon of multidrug resistance (MDR) [1,2]. Anticancer drugs fail to kill cancer cells for various reasons including variations in the absorption, metabolism and delivery of the drug molecule to target tissues and tumor location in parts of the body into which the drugs do not easily penetrate $[3,4,5]$. Despite more than three decades of research on the subject, multidrug resistance remains one of the major obstacles to successful cancer chemotherapy [6]. This phenomenon occurs when cancer cells spontaneously become insensitive to drugs that are structurally unrelated [7]. A leading cause of MDR in cancer is the overexpression of ATPBinding Cassette $(A B C)$ transporters that utilize energy derived from ATP hydrolysis to actively transport anticancer drugs across biological membranes, preventing drugs from reaching their targets within a cancer cell $[8,9]$. Substantial efforts have been carried out to develop potent modulators of $A B C$ drug transporters for the past two decades [10-12]. Unfortunately, these efforts have not provided successful results. The difficulty in finding an ideal inhibitor is often associated with specificity, potency and intrinsic toxicity. Adverse interactions of modulators with drugs administered in parallel or nonspecific side effects are also extremely problematic

*Address correspondence to this author at the Institute of Oncology and Radiology of Serbia, Pasterova 14, 11000 Belgrade, Serbia;

E-mail: stanojkovict@ncrc.ac.rs
[13]. According to previous research data, modulators targeting P-glycoprotein (P-gp)-induced MDR belong to a number of chemical classes and have been classified as the first, second and third generation of MDR reversal agents on the basis of their affinity for the transporter proteins and relative toxicity towards normal cells as marker of their side effects [11, 14, 15]. First generation modulators included drugs that were coincidentally found to be effective in sensitizing the drug resistant tumors towards chemotherapy. These include verapamil, quinine, cyclosporine $A$, tamoxifen and erythromycin $[16,17]$. The second generation modulators constituted drugs that were designed by modification of the first generation modulators and such modifications were aimed at reducing their adverse effects by eliminating their non-MDR pharmacological activities. In this group of drugs are valspodar and Rverapamil $[15,18,19]$. The third generation inhibitors are designed specifically for high transport affinity and low pharmacokinetic interaction [20]. These include tariquidar, biricodar, annamycin, mitotane, zosuquidar, and laniquidar. These compounds exhibit effective and potent MDR modulating activity, high affinity and selectivity for target MDR transporter(s) at low nanomolar range [21, 22]. Nevertheless, most of the agents from the first, second or third generation of MDR modulators suffer clinically from their intrinsic toxicity or from undesired effects on the pharmacokinetics of the accompanying anticancer drugs $[13,23]$.

\section{MDR Modulators from Natural Products}

Inhibitors or modulators originating from natural sources are sometimes referred to as "Fourth

(C) 2020 Neoplasia Research 
Generation Inhibitors". In fact, bioactive compounds from natural products provide one of the most diverse and novel chemical scaffolds suitable for the development of new inhibitors [4,24].

There is a great chemical diversity that can be utilized, as bioactive components are now extracted from plants, fungi and marine organisms, then purified and characterized [25-34]. Most importantly, natural extracts are usually low in toxicity and are well tolerated in the human body $[35,36]$. Accordingly, there have been significant efforts, but the progress in discovering natural MDR inhibitors is still in the early stages of exploring various extracts/active components. The main natural products that have been recognized as modulators of MDR in cancer include: flavonoids, curcumin, lignans; a variety of marine compounds including agosterol $A$ and derivatives, sipholenol $A$, kendarimid $A$, bryostatin-1, lamellarins, ecteinascidin743 [36-38 and references therein]. These substances belong to very different families of chemical compounds. Some of them have very complex structures and their bioactive and anticancer activities effect different levels of tumor cell growth including blocking metabolic/enzymatic reactions, interrupting cell cycle, and direct cell killing. At least a dozen of them are in various phases of clinical trials for the treatment of cancer [39-41].

\section{MDR Modulating Compounds Originating from Marine Organisms}

Marine organisms represent a plentiful source of new bioactive compounds with promising cancer therapeutic potential, including MDR modulation properties [42-45]. A large number of distinctive secondary metabolites isolated from a wide variety of marine microorganisms, plants and invertebrates have been shown to exert anticancer effects. The most significant groups of marine compounds with anticancer properties are alkaloids, anthraquinones, benzothiazoles, macrolides, peptides, sphingolipids,

Table 1: Gives a Brief Overview of the Compounds Isolated Form the Marine Organisms that have been Undergone the Clinical Trials and Found Useful in the Treatment of Cancer in Humans

\begin{tabular}{|c|c|c|c|c|}
\hline Compound name & Origin & $\begin{array}{l}\text { Brand name\& } \\
\text { Manufacturer }\end{array}$ & Indication & Reference \\
\hline Cytarabine & $\begin{array}{c}\text { Caribbean } \\
\text { sponge,Cryptothecacrypta }\end{array}$ & $\begin{array}{c}\text { Cytosar-U, } \\
\text { Ara-C (Phizer), } \\
\text { DepoCyt (Pacira } \\
\text { Pharmaceuticals) }\end{array}$ & $\begin{array}{l}\text { Treatment of cancer and various } \\
\text { types of leukemia }\end{array}$ & [46] \\
\hline $\begin{array}{l}\text { Ecteinascidin-743 } \\
\text { (trabescedine) }\end{array}$ & $\begin{array}{l}\text { Marine tunicates, } \\
\text { Ecteinascidia turbinate }\end{array}$ & Yondelis $®$ (PharmaMar) & Treatment of soft tissue sarcomas & [47] \\
\hline $\begin{array}{l}\text { Erbulinmesylate } \\
\text { (synthetic form of the } \\
\text { natural molecule } \\
\text { halichondrin B) }\end{array}$ & $\begin{array}{l}\text { Halichondrin B was } \\
\text { isolated from marine } \\
\text { sponge Halichondria sp. }\end{array}$ & $\begin{array}{l}\text { Halaven }^{\circledR} \\
\text { (Eisai Inc.) }\end{array}$ & $\begin{array}{c}\text { Treatment of: } \\
\text { - advanced or metastatic breast } \\
\text { cancer; } \\
\text { - unresectableliposarcoma }\end{array}$ & [48] \\
\hline Brentuximabvedotin ( & $\begin{array}{c}\text { Monoclonal antibody } \\
\text { brentuximab with the } \\
\text { monomethyl- auristatin } \mathrm{E} \\
\text { (MMAE), which is a } \\
\text { synthetic analog of } \\
\text { dolastatin-10) } \\
\text { Dolastatin } 10 \text { was found } \\
\text { in the sea } \\
\text { hare Dolabellaauricularia }\end{array}$ & $\begin{array}{c}\text { Adcetris }^{\circledR} \\
\text { (Seattle Genetics) }\end{array}$ & $\begin{array}{c}\text { Treatment of anaplastic large T- } \\
\text { cell systemic malignant } \\
\text { lymphomas and Hodgkin's } \\
\text { lymphomas }\end{array}$ & [49] \\
\hline Enfortumabvedotin & $\begin{array}{l}\text { Antibody, specific to } \\
\text { nectin-4, as conjugate } \\
\text { with MMAE }\end{array}$ & $\begin{array}{c}\text { PADCEVTM }^{\circledR} \\
\text { (Astellas Pharma and } \\
\text { Seattle Genetics) }\end{array}$ & $\begin{array}{c}\text { Treatment of metastatic urothelial } \\
\text { cancer }\end{array}$ & [50] \\
\hline Belantamabmafodotin & $\begin{array}{l}\text { Andtibody-drug conjugate } \\
\text { with MMAE, bound to an } \\
\text { antibody targeting B-cell } \\
\text { maturation antigen }\end{array}$ & Blenrep $^{\circledR}$ (GlaxoSmithKline) & $\begin{array}{l}\text { Treatment of relapsed and } \\
\text { refractory multiple myeloma }\end{array}$ & [51] \\
\hline $\begin{array}{c}\text { Plitidepsin } \\
\text { (dehydrodidemnin B) }\end{array}$ & $\begin{array}{l}\text { Marine tunicate } \\
\text { Aplidiumalbicans }\end{array}$ & $\begin{array}{c}\text { Aplidin }^{\circledR} \\
\text { (PharmMar) }\end{array}$ & $\begin{array}{l}\text { Treatment of leukemia, lymphoma, } \\
\text { and multiple myeloma }\end{array}$ & [52] \\
\hline Lurbinectedin & $\begin{array}{l}\text { Synthetic derivative of } \\
\text { trabectedin }\end{array}$ & $\begin{array}{l}\text { Zepzelca }^{\circledR} \\
\text { (PharmMar) }\end{array}$ & $\begin{array}{l}\text { Treatment of metastatic small cell } \\
\text { lung cancer }\end{array}$ & [53] \\
\hline
\end{tabular}


steroids, tannins, terpenes and terpenoids. Literature data point out the most significant marine sources of novel anticancer agents: sponges, coelenterates, microorganisms, algae, echinoderms, tunicates, mollusks and bryozoans [42 and references cited therein].

Among secondary metabolites of sea sponges a number of P-gp inhibitors were discovered [45]. It has been reported that a sipholane triterpene, sipholenol $A$, isolated from the sponge Callyspongia siphonella efficiently reversed P-gp caused-MDR in malignant cell lines. Sipholenol A increased cytotoxic effect of paclitaxel, vinblastine and colchicines in resistant malignant cell lines [52,54]. One more efficient P-gp inhibitor is polyhydroxylated sterol acetate, agosterol A, found in marine Spongia sp. [55-57]. Furthermore, kendarimide $A$ isolated from the sponge Haliclona sp. has been shown to reverse resistance to colchicine in P-gp overexpressing KB-C2 malignant cell line [58]. Significant class of marine compounds with diverse biological and pharmacological activities including notable potential for overcoming MDR in cancer are lamellarins, polyaromatic alkaloids, which were found in Lamellaria sp., in ascidian, $D$. chartaceum, then in sponge, Dendrillacactos and in species of unidentified ascidians [45]. Interestingly, lamellarin I exert remarkably stronger activity than verapamil in human adenocarcinoma LoVo cells resistant to doxorubicin mediated by direct inhibition of the function of P-gp pump [59]. In addition, it was reported that tetrahydroisoquinoline ecteinascidin-743, also known as trabectedin produced by chemical synthesis, originally isolated from the marine tunicate Ecteinascidia turbinate reversed resistance to doxorubicin and vincristine in MDR epidermal carcinoma P-gp/MDR1 overexpressing cancer cell lines [60]. Trabectedin is the marine-derived orphan drug approved for the treatment of advanced, recurrent soft tissue carcinoma in USA and Switzerland and advanced, recurrent ovarian cancer inUSA and Switzerland [61]. Another effective modulator of P-gp mediated-MDR in cancer cells is bryostatin-1, a macrocyclic lactone, isolated from the marine Bryozoan Bugula neritina, probably a product of symbiont bacteria [62]. Moreover, marine bacteria, cyanobacteria and alga represent notable source of bioactive compounds which MDR modulation properties, such as alkaloids welwitindolinones [63] found in cyanobacteria Hapalosiphon welwitschii, thenbrominated diterpenes, parguerenes I and II derived from the Australian marine red alga Laurencia filiformis [64] and prenylated diketopiperazines no cardio azine $A$ and nocardioazine $\mathrm{B}$ isolated from bacterium Nocardiopsissp. [65].
N-Methylwelwitindolinone-cis-othiocyanate, alcaloid isolated from the blue-green alga Hapalosiphon welwitschii were reported to reverse p-glycoprotein MDR. N-Methylwelwitindolinone $C$ isothiocyanate had MDR efficacy similar to verapamil in two tested cell lines. Also it was shown that $\mathrm{N}$-methylwelwitindolinone $C$ increased the cytotoxicity of actinomycin $D$ and daunomycin [66]. Cyclic peptide, patellamide $d$, isolated from ascidian Lissoclinum patella, has shown cytotoxic activity and resistance in the MDR human leukemic cell line against vinblastine, adriamycin and colchicine [67]. In the marine sponge, Discodermia dissoluta was identified discodermolide, a polyketide, that expressed immunosuppressive and anti-tumor activities [68]. Fordiscodermolide is known that posses the same mechanism of anti-tumor activity as taxol, and its ability to drasticly decrease the MDR to taxol in ovarian carcinoma and pataxel-resistant colon carcinoma cell lines $[69,70]$. Polyoxygenated steroids, first identified in octocoral Isis hippurisare identified in various forms as: gorgosterol, hippuristerone, hippuristanol and hippuristerol types [71].

Many investigators tried to find the potential of wellknown polysaccharide fucoidan, identified in brown algae, as the novel anticancer drug. Unfortunately, despite the cytoprotective activity of fucoidan in uveal melanoma cells and its pro-angiogenic properties, this polysacharide showed no potential to be used as the novel medicine [72]

The extracts derived from marine bacteria family, seaweeds family andmarine invertebrate superfamily, for example Padinapavonia, Halimeda tuna, Codium bursa, Dysideaavara, Axinella cannabina, Achantella acuta, Haliclona mediteranea extracts have shown very strong activity against human malignant cells in vitro [28,29,73-79]. These samples could be promising candidates for testing the ability to overcome MDR in cancer by bioactive compounds such as flavonoids, triterpenoids, quinones, lactones and sesquiterpenes.

\section{CONCLUSION}

The mentioned literature data as well as many others evidence-based data about fourth generation MDR inhibitors indicate that many of these natural products have a synergistic growth inhibitory effect with cancer drugs that are P-gp substrates including actinomycin $\mathrm{D}$, puromycin, paclitaxel, vinblastine and doxorubicin $[3,80,81]$. Also, at the same toxicity levels the natural extracts were found to be more effective than verapamil, a standard MDR modulator, in enhancing cellular doxorubicin accumulation $[82,83]$. 
Finally, natural products represent a starting point for discovery and development of potent and effective MDR modulators, not only for their potential to be used in combination with chemotherapy treatment, but also to rationally design the semi-synthetic QSAR study analogues, with higher potency and fewer pharmacokinetic interactions.

\section{REFERENCES}

[1] Gottesman MM, Fojo T,Bates SE. Multidrug resistance in cancer: role of ATP-dependent transporters. Nat Rev Cancer 2002; 2(1): 48-58 https://doi.org/10.1038/nrc706

[2] Avendaño C, Menendez J. Inhibitors of multidrug resistance to antitumor agents (MDR). Curr Med Chem 2002; 9(2): 159193.

https://doi.org/10.2174/0929867023371175

[3] Ullah MF. Cancer multidrug resistance (MDR): a major impediment to effective chemotherapy. Asian Pac J Cancer Prev 2008; 9(1): 1-6.

[4] Wu CP, Ohnuma S, Ambudkar SV. Discovering natural product modulators to overcome multidrug resistance in cancer chemotherapy. Curr Pharm Biotechnol 2011; 12(4): 609-620. https://doi.org/10.2174/138920111795163887

[5] Ambudkar SV, Dey S, Hrycyna CA, Ramachandra M, Pastan I, Gottesman MM. Biochemical, cellular, and pharmacological aspects of the multidrug transporter. Annu Rev Pharmacol Toxicol 1999; 39(1): 361-398. https://doi.org/10.1146/annurev.pharmtox.39.1.361

[6] Pluchino KM, Hall MD, Goldsborough AS, Callaghan R, Gottesman MM. Collateral sensitivity as a strategy against cancer multidrug resistance. Drug Resist Updat 2012; 15(12): $98-105$ https://doi.org/10.1016/j.drup.2012.03.002

[7] Gottesman MM, Pastan I. Biochemistry of multidrug resistance mediated by the multidrug transporter. Annu Rev Biochem 1993; 62(1): 385-427. https://doi.org/10.1146/annurev.bi.62.070193.002125

[8] Szakács G, Paterson JK, Ludwig JA, Booth-Genthe C, Gottesman MM. Targeting multidrug resistance in cancer. Nat Rev Drug Discov 2006; 5(3): 219-234. https://doi.org/10.1038/nrd1984

[9] Zhou SF. Structure, function and regulation of P-glycoprotein and its clinical relevance in drug disposition. Xenobiotica 2008; 38(7-8): 802-832. https://doi.org/10.1080/00498250701867889

[10] Fox E, Bates SE. Tariquidar (XR9576): a P-glycoprotein drug efflux pump inhibitor. Expert Re Anticancer Ther 2007; 7(4): 447-459.

https://doi.org/10.1586/14737140.7.4.447

[11] Shukla S, Wu CP, Ambudkar SV. Development of inhibitors of ATP-binding cassette drug transporters-present status and challenges. Expert Opin Drug Metab Toxicol 2008; 4(2): 205-223.

https://doi.org/10.1517/17425255.4.2.205

[12] Pusztai L, Wagner P, Ibrahim N, Rivera E, Theriault R, Booser D, et al. Phase II study of tariquidar, a selective P-glycoprotein inhibitor, in patients with chemotherapy-resistant, advanced breast carcinoma. Cancer 2005; 104(4): 682-691.

https://doi.org/10.1002/cncr.21227

[13] Szakács G, Paterson JK, Ludwig JA, Booth-Genthe C, Gottesman MM. Targeting multidrug resistance in cancer. Nat Rev Drug Discov 2006; 5(3): 219-234.

https://doi.org/10.1038/nrd1984
[14] Velingkar VS, Dandekar VD. Modulation od P-glycoprotein mediated multidrug resistance (MDR) in cancer using chemosensitiziers. J Pharm Sci Res 2010; 1(2): 104-111.

[15] Krishna R, Mayer LD. Multidrug resistance (MDR) in cancer: mechanisms, reversal using modulators of MDR and the role of MDR modulators in influencing the pharmacokinetics of anticancer drugs. Eur J Pharm Sci 2000; 11(4): 265-283.

[16] Lampidis TJ, Krishan A, Planas L, Tapiero H. Reversal of intrinsic resistance to adriamycin in normal cells by verapamil. Cancer Drug Deliv 1986; 3(4): 251-259. https://doi.org/10.1089/cdd.1986.3.251

[17] Ford JM, Hait WN. Pharmacology of drugs that alter multidrug resistance in cancer. Pharmacol Rev 1990; 42(3): 155-199.

[18] Höll V, Kouba M, Dietel M, Vogt G. Stereoisomers of calcium antagonists which differ markedly in their potencies as calcium blockers are equally effective in modulating drug transport by P-glycoprotein. Biochem Pharmacol 1992; 43(12): 2601-2608

https://doi.org/10.1016/0006-2952(92)90149-D

[19] te Boekhorst PA, van Kapel J, Schoester M, Sonneveld P. Reversal of typical multidrug resistance by cyclosporin and its non-immunosuppressive analogue SDZ PSC 833 in Chinese hamster ovary cells expressing the mdr 1 phenotype. Cancer Chemother Pharmacol 1992; 30(3): 238-242. https://doi.org/10.1007/BF00686322

[20] Roe M, Folkes A, Ashworth P, Brumwell J, Chima L, Hunjan $\mathrm{S}$, et al. Reversal of P-glycoprotein mediated multidrug resistance by novel anthranilamide derivatives. Bioorg Med Chem Lett 1999; 9(4): 595-600. https://doi.org/10.1016/S0960-894X(99)00030-X

[21] Ullah MF. Cancer multidrug resistance (MDR): a major impediment to effective chemotherapy. Asian Pac J Cancer Prev 2008; 9(1): 1-6.

[22] Liscovitch $M$, Lavie $Y$. Cancer multidrug resistance: a review of recent drug discovery research. Drugs 2002; 5(4): 349355.

[23] Limtrakul P, Siwanon S, Yodkeeree S, Duangrat C. Effect of Stemona curtisii root extract on P-glycoprotein and MRP-1 function in multidrug-resistant cancer cells. Phytomedicine 2007; 14(6): 381-389. https://doi.org/10.1016/j.phymed.2007.03.006

[24] Chearwae W, Anuchapreeda S, Nandigama K, Ambudkar SV, Limtrakul P. Biochemical mechanism of modulation of human P-glycoprotein (ABCB1) by curcumin I, II, and III purified from Turmeric powder. Biochem Pharmacol 2004; 68(10): 2043-2052.

https://doi.org/10.1016/j.bcp.2004.07.009

[25] Cragg GM, Grothaus PG, Newman DJ. Impact of natural products on developing new anti-cancer agents. Chem Rev 2009; 109(7): 3012-3043. https://doi.org/10.1021/cr900019j

[26] Newman DJ, Cragg GM. Natural products as sources of new drugs over the 30 years from 1981 to 2010 . J Nat Prod 2012; 75(3): 311-335.

https://doi.org/10.1021/np200906s

[27] Hu GP, Yuan J, Sun L, She ZG, Wu JH, Lan XJ, et al. Statistical research on marine natural products based on data obtained between 1985 and 2008. Mar Drugs 2011; 9(4): 514-525. https://doi.org/10.3390/md9040514

[28] Stanojković TP, Scaron K, Zdunić G, Kljajić Z, Grozdanić N Antić J. In vitro antitumoral activities of Padina pavonia on human cervix and breast cancer cell lines. J Med Plant Res 2013; 7(8): 419-424.

[29] BožićT, Novaković I, Gašić MJ, Juranić Z, Stanojković T, Tufegdžić $\mathrm{S}$, et al. Synthesis and biological activity of derivatives of the marine quinone avarone. Eur $\mathrm{J}$ Med Chem 2010; 45(3): 923-929.

https://doi.org/10.1016/j.ejmech.2009.11.033 
[30] Sipkema D, Franssen MC, Osinga R, Tramper J, Wijffels RH. Marine sponges as pharmacy. Mar Biotechnol 2005; 7(3): 142-162. https://doi.org/10.1007/s10126-004-0405-5

[31] Sima $P$, Vetvicka V. Bioactive substances with antineoplastic efficacy from marine invertebrates: Porifera and Coelenterata. World J Clin Oncol 2011; 2(11): 355-361. https://doi.org/10.5306/wjco.v2.i11.355

[32] Murti Y, Agrawal T. Marine derived pharmaceuticals-development of natural health products from marine biodiversity. Int $\mathrm{J}$ Chem Tech Research 2010; 2(4): 2198-2217.

[33] Yu Z, Lang G, Kajahn I, Schmaljohann R, Imhoff JF. Scopularides $A$ and $B$, cyclodepsipeptides from a marine sponge-derived fungus, Scopulariopsis brevicaulis. J Nat Prod 2008; 71(6): 1052-1054. https://doi.org/10.1021/np070580e

[34] Gademann K, Sieber S. Chemical interference of biological systems with natural products. CHIMIA 2011; 65(11): 835838.

https://doi.org/10.2533/chimia.2011.835

[35] Patil BS, Jayaprakasha GK, Chidambara Murthy KN, Vikram A. Bioactive compounds: historical perspectives, opportunities, and challenges. J Agric Food Chem 2009; 57(18): 8142-8160.

https://doi.org/10.1021/jf9000132

[36] Crozier A, Jaganath IB, Clifford MN. Dietary phenolics: chemistry, bioavailability and effects on health. Nat Prod Rep 2009; 26(8): 1001-1043 https://doi.org/10.1039/b802662a

[37] Abraham I, El Sayed K, Chen ZS, Guo H. Current status on marine products with reversal effect on cancer multidrug resistance. Mar Drugs 2012; 10(10): 2312-2321. https://doi.org/10.3390/md10102312

[38] Chung SY, Sung MK, Kim NH, Jang JO, Go EJ, Lee HJ.Inhibition of P-glycoprotein by natural products in human breast cancer cells. Arch Pharm Res 2005; 28(7): 823-828. https://doi.org/10.1007/BF02977349

[39] Haefner B. Drugs from the deep: marine natural products as drug candidates. Drug Discov Today 2003; 8(12): 536-544. https://doi.org/10.1016/S1359-6446(03)02713-2

[40] Garcia-Fernandez LF, Reyes F, Sanchez-Puelles JM. The marine pharmacy: new antitumoral compounds from the sea. Pharm News 2002; 9(6): 495-502.

[41] Lechtenberg M, Schepmann D, Niehues M, Hellenbrand N, Wunsch B, Hensel A. Quality and functionality of saffron: quality control, species assortment and affinity of extract and isolated saffron compounds to NMDA and sigma 1 (sigma1) receptors. Planta Med 2008; 74(7):772-764. https://doi.org/10.1055/s-2008-1074535

[42] Chakraborty $\mathrm{C}$, Hsu $\mathrm{CH}$, Wen $\mathrm{ZH}$, Lin CS. Anticancer drugs discovery and development from marine organisms. Curr Top Med Chem 2009; 9(16): 1536-1545. https://doi.org/10.2174/156802609789909803

[43] Sawadogo WR, Schumacher M, Teiten MH, Cerella C, Dicato M, Diederich M. A survey of marine natural compounds and their derivatives with anti-cancer activity reported in 2011. Molecules 2013; 18(4): 3641-3673. https://doi.org/10.3390/molecules 18043641

[44] Senthilkumar K, Kim SK. Marine invertebrate natural products for anti-inflammatory and chronic diseases. Evid Based Complement Alternat Med 2013; 2013: 1-10. https://doi.org/10.1155/2013/572859

[45] Lopez D, Martinez-Luis S. Marine natural products with Pglycoprotein inhibitor properties. Mar Drugs 2014; 12(1): 525546.

https://doi.org/10.3390/md12010525

[46] Mayer AM, Glaser KB, Cuevas C, Jacobs RS, Kem W, Little $\mathrm{RD}$, et al. The odyssey of marine pharmaceuticals: A current pipeline perspective. Trends Pharmacol Sci 2010; 31: 255265

https://doi.org/10.1016/j.tips.2010.02.005
[47] Garcia-Carbonero R, Supko JG, Maki RG, Manola J, Ryan DP, Harmon D, et al. Ecteinascidin-743 (ET-743) for chemotherapy-naive patients with advanced soft tissue sarcomas: multicenter phase II and pharmacokinetic study. J Clin Oncol 2005; 23(24): 5484-5492. https://doi.org/10.1200/JCO.2005.05.028

[48] McBride A, Butler SK. Eribulin mesylate: a novel halichondrin $B$ analogue for the treatment of metastatic breast cancer. Am J Health Syst Pharm 2012; 69(9): 745-755. https://doi.org/10.2146/ajhp110237

[49] Dyshlovoy SA. Honecker F. Marine compounds and cancer: The first two decades of XXI century. Mar Drugs 2020; 18(1): 20-24.

https://doi.org/10.3390/md18010020

[50] Hanna KS. Enfortumab vedotin to treat urothelial carcinoma. Drugs Today (Barc) 2020; 56(5): 329-335. https://doi.org/10.1358/dot.2020.56.5.3127027

[51] Markham A. Belantamab M. First Approval. Drugs 2020; 80: 1607-1613.

https://doi.org/10.1007/s40265-020-01404-x

[52] Australian Public Assessment Report; The Therapeutic Goods Administration, Department of Health, Australian Government: Symonston, Australia for Plitidepsin. Available from: https://www.tga.gov.au/sites/default/files/ausparplitidepsin-190513.pdf

[53] Markham, A. Lurbinectedin: First Approval. Drugs 2020; 80: 1345-1353. https://doi.org/10.1007/s40265-020-01374-0

[54] Shi Z, Jain S, Kim IW, Peng XX, Abraham I, Youssef DT, et al. Sipholenol A, a marine-derived sipholane triterpene, potently reverses P-glycoprotein (ABCB1)-mediated multidrug resistance in cancer cells. Cancer Sci 2007; 98(9): 1373-1380.

https://doi.org/10.1111/j.1349-7006.2007.00554.x

[55] Jain S, Abraham I, Carvalho P, Kuang YH, Shaala LA, Youssef DT, et al. Sipholane triterpenoids: Chemistry, reversal of $A B C B 1 / P$-glycoprotein-mediated multidrug resistance, and pharmacophore modeling. J Nat Prod 2009; 72(7): 1291-1298. https://doi.org/10.1021/np900091y

[56] Aoki S, Yoshioka Y, Miyamoto Y, Higuchi K, Setiawan A Murakami N, et al. Agosterol A, a novel polyhydroxylated sterol acetate reversing multidrug resistance from a marine sponge of Spongia sp. Tetrahedron Lett 1998; 39(35): 63036306.

https://doi.org/10.1016/S0040-4039(98)01336-7

[57] Aoki S, Chen ZS, Higasiyama K, Setiawan I, Akiyama SI, Kobayashi M. Reversing effect of agosterol $A$, a spongean sterol acetate, on multidrug resistance in human carcinoma cells. Jpn J Cancer Res 2001; 92(8): 886-895. https://doi.org/10.1111//.1349-7006.2001.tb01177.x

[58] Chen ZS, Aoki S, Komatsu M, Ueda K, Sumizawa T, Furukawa $\mathrm{T}$, et al. Reversal of drug resistance mediated by multidrug resistance protein (MRP) 1 by dual effects of agosterol A on MRP1 function. Int J Cancer 2001; 93(1): 107113.

https://doi.org/10.1002/ijc.1290

[59] Aoki S. Cao L. Matsui K. Rachmat R. Akiyama S.I. Kobayashi $M$. Kendarimide $A$, a novel peptide reversing $P$ glycoprotein-mediated multidrug resistance in tumor cells, from a marine sponge of Haliclona sp. Tetrahedron 2004; 60(33): 7053-7059. https://doi.org/10.1016/j.tet.2003.07.020

[60] Quesada AR, Grávalos MG, Puentes JF. Polyaromatic alkaloids from marine invertebrates as cytotoxic compounds and inhibitors of multidrug resistance caused by $P$ glycoprotein. Br J Cancer 1996; 74(5): 677-682. https://doi.org/10.1038/bjc.1996.421

[61] Kanzaki A, Takebayashi $Y$, Ren $X Q$, Miyashita H, Mori S, Akiyama $\mathrm{SI}$, et al. Overcoming multidrug drug resistance in 
P-glycoprotein/MDR1-overexpressing cell lines by ecteinascidin 743. Mol Cancer Ther 2002; 1(14): 1327-1334.

[62] Carter NJ, Keam SJ. A Review of its Use in Soft Tissue Sarcoma and Ovarian Cancer. Trabectedin. Drugs 2010; 70(3): 355-376.

https://doi.org/10.2165/11202860-000000000-00000

[63] Spitaler M, Utz I, Hilbe W, Hofmann J, Grunicke H. PKCindependent modulation of multidrug resistance in cells with mutant (V185) but not wild-type (G185) P-glycoprotein by bryostatin 1. Biochem Pharmacol 1998; 56(7): 861-869. https://doi.org/10.1016/S0006-2952(98)00107-5

[64] Smith CD, Zilfou JT, Stratmann K, Patterson GM,Moore RE. Welwitindolinone analogues that reverse P-glycoproteinmediated multiple drug resistance. Mol Pharmacol 1995; 47(2): 241-247.

[65] Huang XC, Sun YL, Salim AA, Chen ZS, Capon RJ. Parguerenes: Marine red alga bromoditerpenes as inhibitors of P-glycoprotein (ABCB1) in multidrug resistant human cancer cells. Biochem Pharmacol 2013; 85(9): 1257-1268. https://doi.org/10.1016/j.bcp.2013.02.005

[66] Raju R, Piggott AM, Huang XC, Capon RJ. Nocardioazines: A novel bridged diketopiperazine scaffold from a marinederived bacterium inhibits P-glycoprotein. Org Lett 2011; 13(10): 2770-2773.

https://doi.org/10.1021/ol200904v

[67] Smith CD, Zilfou JT, Stratmann K, Patterson GM, Moore RE. Welwitindolinone analogues that reverse P-glycoproteinmediated multiple drug resistance. Mol Pharmacol 1995; 47(2): 241-247.

[68] Degnan M, Hawkins CJ, Lavin MF, McCaffrey EJ, Parry DL, Van den Brenk AL, et al. New cyclic peptides with cytotoxic activity from the ascidian Lissoclinum patella. J Med Chem 1989; 32(6): 1349-1354.

https://doi.org/10.1021/jm00126a034

[69] Gunasekera SP, Gunasekera M, Longley RE, Schulte GK. Discodermolide: a new bioactive polyhydroxylated lactone from the marine sponge Discodermia dissoluta. J Org Chem 1990; 55(16): 4912-4915.

https://doi.org/10.1021/jo00303a029

[70] Kalesse $M$. The chemistry and biology of discodermolide. ChemBioChem 2000; 1(3): 171-175

https://doi.org/10.1002/1439-7633(20001002)1:3<171::AIDCBIC171>3.0.CO;2-D

[71] Kowalski RJ, Giannakakou P, Gunasekera SP, Longley RE, Day BW, Hamel E. The microtubule-stabilizing agent discodermolide competitively inhibits the binding of paclitaxel (Taxol) to tubulin polymers, enhances tubulin nucleation reactions more potently than paclitaxel, and inhibits the growth of paclitaxel-resistant cells. Mol Pharmacol 1997; 52(4): 613-622.

https://doi.org/10.1124/mol.52.4.613

[72] Dithmer M, Kirsch AM, Richert E, Fuchs S, Wang F, Schmidt $\mathrm{H}$, et al. Fucoidan does not exert anti-tumorigenic effects on uveal melanoma cell lines. Mar Drugs 2017; 15(7): 193-207. https://doi.org/10.3390/md15070193
[73] Chen WH, Wang SK, Duh CY. Polyhydroxylated steroids from the bamboo coral Isis hippuris. Mar Drugs 2011; 9(10): 1829-1839. https://doi.org/10.3390/md9101829

[74] Kljajić Z, Dogović N, Gašić MJ. Sterols in adriatic sea ascidians. Comp Biochem Physiol 1983; 75(3): 519-521. https://doi.org/10.1016/0305-0491(83)90369-3

[75] Muller WEG, Diehl-Seifert B, Sobel C, Bechtold A, Kljajic Z,Dorn A Sponge secondary metabolites: biochemical and ultrastructural localization of the antimitotic agent avarol in Dysidea avara. J Histochem Cytochem (1986); 34(12): 16871690. https://doi.org/10.1177/34.12.3782777

[76] Müller WEG, Sobel C, Sachsse W, Diehl-Seifert B, Zahn RK Eich E, et al. Biphasic and differential effects of the cytostatic agents avarone and avarol on DNA metabolism of human and murine $\mathrm{T}$ and $\mathrm{B}$ lymphocytes. Eur $\mathrm{J}$ Cancer Clin Oncol 1986; 22(4): 473-476.

https://doi.org/10.1016/0277-5379(86)90114-8

[77] Kreuter $\mathrm{MH}$, Bernd A, Holzmann $\mathrm{H}$, Müller-Klieser $\mathrm{W}$, Maidhof A, Weissmann $\mathrm{N}$, et al. Cytostatic activity of aeroplysinin-1 against lymphoma and epithelioma cells. Naturforschung 1989; 44(7-8): 680-688. https://doi.org/10.1515/znc-1989-7-822

[78] Kreuter $M H$, Robitzki A, Chang S, Steffen R, Michaelis $M$, Kljajić Z, et al. Production of the cytostatic agent aeroplysinin by the sponge Verongia aerophoba in in vitro culture. Comp Biochem Physiol C Toxicol Pharmacol 1992; 101(1): 183187.

https://doi.org/10.1016/0742-8413(92)90217-U

[79] Pajic I, Kljajic Z, Dogovic N, Sladic D, Juranic Z, Gasic MJ. A novel lectin from the sponge Haliclona cratera: isolation, characterization and biological activity. Comp Biochem Physiol C Toxicol Pharmacol 2002; 132(2): 213-221. https://doi.org/10.1016/S1532-0456(02)00068-6

[80] Fong WF, Wang C, Zhu GY, Leung CH, Yang MS, Cheung $\mathrm{HY}$. Reversal of multidrug resistance in cancer cells by Rhizoma Alismatis extract. Phytomedicine 2007; 14(2-3): 160-165.

https://doi.org/10.1016/j.phymed.2006.03.004

[81] Engi H, Vasas A, Redei D, Molnár J, Hohmann J. New MDR modulators and apoptosis inducers from Euphorbia species. Anticancer Research 2007; 27(5A): 3451-3458.

[82] Bansal $T$, Jaggi $M$, Khar R, Talegaonkar S. Emerging significance of flavonoids as P-glycoprotein inhibitors in cancer chemotherapy. J Pharm Pharmaceut Sci 2009; 12(1): 46-78. https://doi.org/10.18433/J3RC77

[83] Abraham I, El Sayed K, Chen ZS, Guo H. Current status on marine products with reversal effect on cancer multidrug resistance. Mar Drugs 2012; 10(10): 2312-2321. https://doi.org/10.3390/md10102312

\section{DOI: https://doi.org/10.30683/1929-2279.2020.09.11}

(C) 2020 Stanojkovic and Milovic; Licensee Neoplasia Research.

This is an open access article licensed under the terms of the Creative Commons Attribution Non-Commercial License (http://creativecommons.org/licenses/by-nc/3.0/) which permits unrestricted, non-commercial use, distribution and reproduction in any medium, provided the work is properly cited. 